Bulletin UASVM Food Science and Technology 70(2)/2013, 93-98

ISSN-L 2344-2344; Print ISSN 2344-2344; Electronic ISSN 2344-5300

\title{
Study of Valorification of Lycium barbarum (Goji) in Pastry Products
}

\section{Anamaria POP, Sevastiţa MUSTE, Simona MAN, Crina MUREŞAN}

Faculty of Food Science and Technology, University of Agricultural Sciences and Veterinary Medicine Cluj-Napoca; 3-5 Mănăştur street, 3400, Cluj-Napoca, Romania; *ing.anamariapop@ gmail.com

\begin{abstract}
The aim of this research refers to the development of new recipes of fabricating two different muffins and spritz cookies, using Goji whole fruits rehydrated and Goji ground powder type fruits, in different proportions and after, by sensory analysis proving the consumer preferences in relation to Goji fruit intake in the products. It has been also studied the total carotenoid content by spectrophotometric measurements from finished products comparing with whole goji berry fruit. The products are obtained by baking dough made from flour, sugar, eggs, vegetable fat, milk, goji berries, friable chemical. The raw material and auxiliary material (white flour and Goji berries) and the pastry products obtain with addition of goji was submitted to the physio-chemical exam, following: moisture content, ash content, gluten content, acidity content, vitamin $\mathrm{C}$ content, carotenoids content in accordance with applicable standards. Therefore we obtained 3 types of muffins (simple muffins, muffins with addition of $10 \%$ whole goji fruit, muffins with addition of $10 \%$ fruit goji powder ground type) and 4 types of spritz cookies (simple cookies, cookies with addition of $3 \%, 5 \%, 10 \%$ of goji powder).
\end{abstract}

Keywords: goji, pastry, cookies, muffins, techonolgy, sensoryal analysis

\section{INTRODUCTION}

Lycium barbarum L. (L. barbarum) is a Solanaceous defoliated shrubbery that grows in China, Tibet and other parts of Asia and its fruits are 1-2 cm-long, bright orange-red ellipsoid berries (Fig. 1). Lycium barbarum fruit (Goji) is a powerful super food, contain more betacarotene than any food on earth and more than 500 times the vitamin $\mathrm{C}$ of oranges by weight, more calcium than cauliflower, more protein than bee pollen (it's $16 \%$ protein by weight, making it a high-protein fruit), more beta carotene than carrots, essential fatty acids, and vitamins (Moffett Alex, 2008). A ripe fruit it is used in Asian countries as a traditional herbal medicine and functional food (Bensky and Gamble, 1993; Bryan et al., 2008; Chang and But, 2001; Zhu, 1998). Concentrated extracts and infusions prepared from the berries have a history of use as ingredients in various soft or alcoholic drinks that were marketed (UK Food Standard Agency, 2007) for their benefits to anti-aging, vision, kidney and liver functions. Some of the scientific research findings reported about the Goji include:contains 19 amino acids-(six times higher than bee pollen), contains 21 trace minerals, including germanium, an anti-cancer trace mineral, contains more protein than whole wheat, contains a complete spectrum of antioxidant carotenoids, contains 500 times the amount of Vitamin $\mathrm{C}$ by weight than oranges, contains Bcomplex, contains vitamin E, contains Beta-Sitosterol, an anti-inflammatory agent; also lowers cholesterol and used to treat sexual impotence and prostate enlargement, contains essential fatty acids, contains Cyperone, a sesquiterpene that benefits the heart and blood pressure, contains Solavetivone, an anti-fungal and anti-bacterial compound (dr. Earl Mindell, and Rick Handel, Goji: The Himalyan Health Secret). 
Nutritional facts information for goji berries Per $100 \mathrm{~g}$ : Protein $1.5 \mathrm{~g}-10.6 \mathrm{~g}$, Total Fat $0.5 \mathrm{~g}-3.6 \mathrm{~g}$, Total Carbohydrate $3.1 \mathrm{~g}-22 \mathrm{~g}$, Cholesterol $0.0 \mathrm{mg}-0.0 \mathrm{mg}$, Sugars $2.4 \mathrm{~g}-17.1 \mathrm{~g}$, Polysaccharides $6.9 \mathrm{~g}-49 \mathrm{mg}$, Water $<15 \%$ (MAX) - <15\% (MAX), Dietary Fiber 1.04g - 7.4g, Selenium, (Se) $7.02 \mu \mathrm{g}$ (micro grams) - $50 \mu \mathrm{g}$ (micrograms), Sodium, (Na) $3.1 \mathrm{mg}-22 \mathrm{mg}$, Potassium, (K) $158.65 \mathrm{mg}-1,130 \mathrm{mg}$, Zinc, (Zn) $0.3 \mathrm{mg}-2 \mathrm{mg}$, Calcium, (Ca) $15.7 \mathrm{mg}-112$ $\mathrm{mg}$, Iron, $(\mathrm{Fe}) 1.18 \mathrm{mg}-8.42 \mathrm{mg}$, Vitamin $\mathrm{C}$ - (ascorbic acid) $2.6 \mathrm{mg}-18.4 \mathrm{mg}$, Beta-carotene $1.05 \mathrm{mg}-7.45 \mathrm{mg}$, Thiamin (vitamin B1) $0.02 \mathrm{mg}-0.16 \mathrm{mg}$, Riboflavin (vitamin B2) $0.2 \mathrm{mg}-$ $1.3 \mathrm{mg}$, Zeaxanthin 11.6 to $28.1 \mathrm{mg}-82.5$ to $200 \mathrm{mg}$, Amino acids $1.2 \mathrm{mg}-8.37 \mathrm{mg}$ (http://convert-to.com/634/dry-goji-berry-conversion-and-goji-nutritional-facts.html).

In the competitive of the market economy emergence of a new pastry product is offered opportunity in confrontation with other similar products, the main objective is winning market share by offering quality products with high nutritional value at a price as low as possible which implies the optimal use of raw materials and utilities specific to a greater degree of mechanization and automation with modern equipment, highly skilled personnel.



Fig. 1. Pictures of Lycium barbarum fruit

\section{MATERIALS AND METHODS}

The research has been carried out at the Faculty of Food Science and Technology, Bakery and Pastry Pilot Station for to achieve the technological part of the products and at the Laboratory of Food Quality Control to achieve control part of the products. All raw materials used in these experiments have been purchased from markets of specialized stores. The research was conducted around four major objectives. The first goal was to establishing main physicochemical parameters of raw materials and auxiliary materials studied. To achieve this goal has been determined ash content (in flour), wet gluten (in flour), moisture content (flour and goji), acidity content (flour and goji), and content of vitamin $\mathrm{C}$ (goji). All determinations were performed according to current standards of food quality control (Tab. 1).

The second goal was to establishing manufacturing technology of two types of pastries (muffins and spritz cookies) using addition of whole goji berries and goji berries milled powder type in various proportions. In this sense have been established manufacturing recipes and technological schemes for each finished product in part. For obtaining goji whole fruit muffins we used the following quantities of raw and auxiliary materials: 2 eggs, $200 \mathrm{~g}$ sugar $200 \mathrm{ml}$ oil $200 \mathrm{ml}$ milk, $1 / 2$ teaspoon salt, 1 sachet baking powder, 1 sachet vanilla sugar $400 \mathrm{~g}$ flour $100 \mathrm{~g}$ whole rehydrated goji berries (soaked in water for $30 \mathrm{~min}$ ). For obtaining goji powder muffins was used the same quantities of raw and auxiliary materials difference is that the goji fruit was mill ground type like a powder. For obtain spritz cookies with added goji powder was attempted and achieved many variations depending on the intake of goji powder in the recipe, because was intended optimize the addition of goji berries in spritz cookies. Thus, in order to test the consumer's preference for such products have been developed four types of biscuits (spritz 
cookies): simple biscuits, biscuits 3\% goji berries powder, biscuits 5\% goji berries powder, biscuits $10 \%$ milled goji powder. For obtain biscuits with added goji powder was used the following quantities of raw and auxiliary materials: flour - 500g butter - 200g sugar - 200g-1 sachet vanilla sugar, eggs - 1 piece salt - 1g, baking powder, goji berries ground type powder (30 $\mathrm{g}$ representing $3 \%, 50 \mathrm{~g}$ of $5 \%$ and $10 \mathrm{~g}$ of $10 \%$ ). obtained.

The third goal was to determine the carotenoid content of the two types of products

It was decided to test the carotenoids content in muffins with added $10 \%$ goji whole fruit and cookies with the addition of 5\% goji berries powdered. The carotenoids were performed according to current standards (Tab. 1).

Tab. 1

Analyses performed on all raw materials according to proposed objective

\begin{tabular}{|c|c|c|}
\hline Parameters followed & The method used & Equipment used \\
\hline Ash content & STAS $90-98$ & $\begin{array}{l}\text { Calciner thermoregulation, anhydrous } \\
\text { calcium chloride desiccator, the crucible. }\end{array}$ \\
\hline Wet gluten & & $\begin{array}{l}\text { Analytical balance, pestle and mortar, } \\
\text { sieve }\end{array}$ \\
\hline Moisture content & STAS $90-98$ & $\begin{array}{l}\text { Thermoregulation } \\
\text { analytical balance }\end{array} \begin{array}{c}\text { electric } \text { with weighing } \\
\text { accuracy of } \pm 0.001 \mathrm{~g} \text {, weighing vials } \\
\text { with cover desiccator }\end{array}$ \\
\hline Acidity content & $\begin{array}{c}\text { Method of ethyl alcohol } \\
67 \%(\mathrm{v} / \mathrm{v})\end{array}$ & Erlenmeyer flask, cone, pipette, \\
\hline $\begin{array}{l}\text { Vitamin C (ascorbic } \\
\text { acid) }\end{array}$ & STAS 5950-85 & Titration equipment, pestle and mortar, \\
\hline Carotenoid content & STAS 13058-91 & $\begin{array}{l}\text { Analytical balance weighing accuracy of } \\
\pm 0.001 \mathrm{~g} \text {, Rotavapor, Spectrophotometer } \\
\text { UV / VIS }\end{array}$ \\
\hline
\end{tabular}

The last goal was to testing with the help of sensory analysis of consumer preferences for the products. In this case, the aim pursued by sensory analysis is to test consumer preferences for a possible placing of the market of new products made. In this sense, particularly preferred method, the hedonic scale. This method is not to perform an analysis to determine the precise sensory qualities of the product but involves the selection of preferred sample of a certain number of samples representing different types of the same product.

For the examination samples was used in a number of 80 tasters, teachers and students from the Faculty of Food Science and Technology, University of Agricultural Sciences and Veterinary Medicine Cluj-Napoca.

\section{RESULTS AND DISCUSSIONS}

In terms of raw material, Băneasa flour type 000, fall in organoleptic and physicochemical parameters. In terms of color and appearance, the Goji fruits are small, oblong, orange, smell is pleasant specific fruit without the smell of mold, musty or other foreign smell; specific taste sweet and sour. In terms of auxiliary materials, goji fruit falls in physico-chemical quality parameters according to standards (Tab. 2). 
After applying sensory analysis on 80 subjects of the three samples of muffins, muffins sample with addition of $10 \%$ whole goji berries are preferred by consumers. As can be seen from the cumulative record of tasting any of the three samples analyzed did not record percentage of "dislike". Sample code 111 (simple muffins) obtained as average appreciation "I like" sample code 222 (muffins with added 10\% goji whole fruit) obtained as average appreciation "I like very much" and 333 sample (added 10 muffins \% goji berries powder) obtained as average appreciation "I really like.".

Tab. 2

Quality parameters results

\begin{tabular}{|l|l|c|}
\hline Raw and auxiliary materials & Quality parameters & Results \\
\hline \multirow{4}{*}{ Flour } & Moisture content & $12,23 \%$ \\
\cline { 2 - 3 } & Ash content & $0.43 \%$ \\
\cline { 2 - 3 } & Wet gluten & $32.3 \%$ \\
\cline { 2 - 3 } & Acidity & $1,85^{\circ}$ \\
\hline \multirow{3}{*}{ Goji } & Moisture content & $8,1 \%$ \\
\cline { 2 - 3 } & Vitamin C(ascorbic acid) & $131,33 \mathrm{mg} \%$ \\
\cline { 2 - 3 } & Acidity & $0,4601 \mathrm{~g} . \%$ acid malic \\
\hline
\end{tabular}

Tab. 3

Cumulative data tasting for muffins

\begin{tabular}{|l|l|l|l|l|}
\hline \multirow{2}{*}{ The estimation level } & Findings & \multicolumn{4}{|l|}{ Assessment of the evidence } \\
\cline { 3 - 5 } & value & 111 & 222 & 333 \\
\hline I like it very much & 9 & 4 & 40 & 12 \\
\hline I really like & 8 & 16 & 24 & $\mathbf{3 2}$ \\
\hline I like moderate & 7 & 24 & 16 & 8 \\
\hline I like & 6 & 36 & 0 & 28 \\
\hline I do not like nor dislike & 5 & 0 & 0 & 0 \\
\hline I hate & 4 & 0 & 0 & 0 \\
\hline I dislike moderately & 3 & 0 & 0 & 0 \\
\hline I dislike very much & 2 & 0 & 0 & 0 \\
\hline I dislike very much & 1 & 0 & 0 & 0 \\
\hline Total & & 80 & 80 & 80 \\
average value & $\mathbf{6 . 8 5}$ & $\mathbf{8 . 3}$ & $\mathbf{7 . 3 5}$ \\
Percentage of "dislike" \% & 0 & 0 & 0 \\
\hline
\end{tabular}

Products: 111: simple muffins

222: muffins with addition of $10 \%$ whole fruit goji

333: muffins with addition of $10 \%$ whole fruit powder

In the case of spritz cookies after applying sensory analysis on the same 80 subjects, cookies with addition of $5 \%$ of goji powder are preferred by consumers.

From the analyzed samples a higher content of carotenoids has been shown to goji whole fruit muffins. The method are based on a rapid extraction protocol and spectrophotometric measurements to determine the total amount carotenoids present in pastry products with the addition of goji fruits. 
Tab. 4

Cumulative data tasting for spritz cookies

\begin{tabular}{|l|l|l|l|l|l|}
\hline The estimation level & Findings & \multicolumn{5}{|c|}{ Assessment of the evidence } \\
\cline { 3 - 6 } & value & 111 & 222 & 333 & 444 \\
\hline I like it very much & 9 & 4 & 16 & 24 & 16 \\
\hline I really like & 8 & 16 & 32 & 40 & 16 \\
\hline I like moderate & 7 & 22 & 16 & 8 & 28 \\
\hline I like & 6 & 8 & 16 & 8 & 8 \\
\hline I do not like nor dislike & 5 & 4 & 0 & 0 & 0 \\
\hline I hate & 4 & 24 & 0 & 0 & 12 \\
\hline I dislike moderately & 3 & 2 & 0 & 0 & 0 \\
\hline I dislike very much & 2 & 0 & 0 & 0 & 0 \\
\hline I dislike very much & 1 & 0 & 0 & 0 & 0 \\
\hline Total & 80 & 80 & 80 & 80 \\
average value & $\mathbf{5 . 8 5}$ & $\mathbf{7 . 6}$ & $\mathbf{8}$ & $\mathbf{7 . 0 5}$ \\
Percentage of "dislike" \% & 32.5 & 0 & 0 & 15 \\
\hline
\end{tabular}

Products: 111: simple spritz cookies

222: spritz cookies with addition of $3 \%$ goji powder

333: spritz cookies with addition of $5 \%$ goji powder

444: spritz cookies with addition of $10 \%$ goji powder

To have a comparation of the results, studies have found with the specialty literature regards the carotenoid profile which was obtained for some wheat species investigated, but significant differences were observed in the concentration of carotenoids. Einkorn (Triticum monococcum) exhibited the highest level of all-trans-lutein, averaging $7.41 \mathrm{microg} / \mathrm{g}$ with small amounts of all-trans-zeaxanthin, cis-lutein isomers, and beta-carotene. Durum, Kamut, and Khorasan (Triticum turgidum) had intermediate levels of lutein (5.41-5.77 microg/g), while common bread or pastry wheat (Triticum aestivum) had the lowest content (2.01-2.11 microg/g). Lutein in einkorn appeared to be influenced significantly by environmental growing conditions. As can be seen a higher content of carotenoids has been shown to goji whole fruit muffins compared to spritz cookies.

Tab. 5

Total carotenoid content in the pastry products obtained

\begin{tabular}{|c|c|}
\hline Product Type & Total carotenoid content \\
\hline $\mathrm{P} 1$ & $96,53 \mu \mathrm{g} / \mathrm{g} \mathrm{SU}=0.096 \mathrm{mg} / \mathrm{SUg}$ \\
\hline $\mathrm{P} 2$ & $38,84 \mu \mathrm{g} / \mathrm{g} \mathrm{SU}=0.038 \mathrm{mg} / \mathrm{SUg}$ \\
\hline
\end{tabular}

$\mathrm{P} 1=$ muffins with addition of $10 \%$ whole fruit powder

$\mathrm{P} 2=$ spritz cookies with addition of $5 \%$ goji powder 


\section{CONCLUSION}

In the present research work, was demonstrated that valorification of Lycium Barbarum fruit (Goji) is suitable in pastry products.

$\checkmark$ Flour and goji fruit fall into studied physico-chemical quality parameters according to standards.

$\checkmark$ Out of the three samples muffins in sensory analysis, sample muffins with added $10 \%$ goji whole fruit is preferred by consumers.

$\checkmark$ From the four sample of biscuits in sensory analysis, sample biscuits $5 \%$ powdered goji berries are preferred by consumers.

$\checkmark$ Fruit prints made products taste sour and slightly sweet and a specific flavor.

Through this study we have established new manufacturing recipes for muffins and spritz cookies using rehydrated goji berries and goji berries whole powdered ground type.

\section{REFERENCES}

1. Abdel-Aal el-SM, Young JC, Rabalski I, Hucl P, Fregeau-Reid J., Identification and quantification of seed carotenoids in selected wheat species. J Agric Food Chem. 7;55(3):787-94.

2. Bensky, D., \& Gamble, A. (1993). Gou Qi Zi. Chinese Herbal Medicine, Materia Medica (pp. 333-334). (revised ed). Seattle, Washington: Eastland Press, Inc.

3. Chang, R. C., \& So, K. F. (2008). Use of anti-aging herbal medicine, Lycium barbarum, against aging-associated diseases. What do we know so far? Cellular and Molecular Neurobiology, 28(5), 643-652.

4. Earl Mindell , Rick Handel, 2003, Goji: The Himalyan Health Secret, ISBN: 0-9672855-2-6

5. Harunobu A.,Norman R, 2011, A review of botanical characteristics, phytochemistry, clinical relevance in efficacy and safety of Lycium barbarum fruit (Goji), Food Research International 44 (2011) $1702-1717$

6. Moffett A., 2008, Terapeutic composition from goji (Licium barbarum L.) methods of making and using, Patent aplication publication, Pub.No. US2008/0124416A1

7. Mureșan Crina, Muste Sevastița, 2011, Controlul calității materiilor prime de origine vegetală Caiet de lucrări practice, Editura AcademicPres, Cluj Napoca

8. Segal Rodica,2006, Analiza senzorială a produselor alimentare, Editura tehnică, București

9. http://convert-to.com/634/dry-goji-berry-conversion-and-goji-nutritional-facts.html 